\title{
ARTICLES
}

Submitted 10.15.2017. Approved 03.22.2018

Evaluated through a double-blind review process. Guest Scientific Editors: Luciano Batista and Eliciane Maria da Silva

Original version

DOI: http://dx.doi.org/10.1590/So034-759020180503

\section{INTEGRATION BETWEEN RESEARCH AND DEVELOPMENT: A DYNAMIC CAPABILITIES PERSPECTIVE}

\author{
Integração entre pesquisa e desenvolvimento: Uma perspectiva de \\ capacidades dinâmicas
}

\author{
Integración entre investigación y desarrollo: Una perspectiva de capacidades \\ dinámicas
}

\begin{abstract}
Integration between research (R) and development (D) activities when they are organized separately in companies as specific departments is crucial for innovation performance and for the firm's adaptation and growth. Although this is of utmost importance, paradoxically, very few studies have focused on it. Considering this integration as a dynamic capability, through a systematic literature review on integration models and dynamic capabilities, we discuss distinctive views of the concept and the ways in which they can be applied. This study leads to the systematization of this knowledge field and to the identification of gaps in the literature on the integration between $R$ and $D$. A research agenda is also proposed.
\end{abstract}

KEYWORDS | Dynamic capabilities, integration, research, development, conciliatory model.

\section{RESUMO}

A integração entre as atividades de pesquisa $(P)$ e desenvolvimento $(D)$, quando são organizadas separadamente nas empresas como departamentos específicos, é crucial para o desempenho da inovação e para a habilidade de adaptação e crescimento das empresas. Embora seja de extrema importância, paradoxalmente, muito poucos estudos focaram esse tema. Considerando integração uma capacidade dinâmica, por meio de uma revisão sistemática da literatura de modelos de integração e capacidades dinâmicas, discutimos diferentes visões do conceito e de que formas pode ser aplicado. Este estudo contribui para a sistematização desse campo de conhecimento, para identificação de lacunas na literatura de integração entre $P$ e D. Uma agenda de pesquisa também é proposta.

PALAVRAS-CHAVE: Capacidades dinâmicas, integração, pesquisa, desenvolvimento, modelo conciliatório.

FELIPE PLANA MARANZATO ${ }^{1}$

fpmaranzato@usp.br ORCID 0000-0002-0165-7747

\section{MÁRIO SERGIO SALERNO ${ }^{1}$ \\ msalerno@usp.br}

ORCID 0000-0002-2025-2534

${ }^{1}$ Universidade de São Paulo, Escola Politécnica, Departamento de Engenharia de Produção, São Paulo, SP, Brazil

\section{RESUMEN}

La integración entre las actividades de investigación (I) y de desarrollo (D), cuando se organizan separadamente, como departamentos específicos en las empresas, es crucial para el desempeño de la innovación y para la capacidad de adaptación y crecimiento de las empresas. Aunque sea de suma importancia, paradójicamente, muy pocos estudios se han centrado en este tema. Considerando esta integración como una capacitación dinámica, realizamos una revisión bibliográfica sistemática sobre los modelos de integración y de capacitaciones dinámicas, discutimos los puntos de vista distintivos del concepto y cómo se puede aplicarlo. Este estudio contribuye a la sistematización de este campo de conocimiento, para la identificación de lagunas en la literatura de integración entre l y D. También se propone una agenda de investigación.

PALABRAS CLAVE: Capacidades dinámicas, integración, investigación, desarrollo, modelo conciliatorio. 


\section{INTRODUCTION}

Research and development (R\&D) are typically seen as a single organizational function (department). Several studies have related R\&D integration with marketing or with production. However, Chiesa (1996) points out that in terms of culture, organizational arrangements and behaviors, and characteristics of people, research is quite different from development (Chiesa, 1996). Little is known about the complex integration between " $R$ " for "research" and "D" for "development" when these functions are separated inside an organization (Iansiti, 1995a).

Integration between the activities of $R$ and of $D$ is crucial for organizations with a clear strategic intent for innovation. In brief, research must develop new technologies that leverage new businesses platforms and development has to design successfully new products and processes or new versions of existing ones. Research is more attached to science and general technological principles and development relates more to marketing, consumers, and forms of product use. Problems in the integration of the two may imply research working and delivering technology platforms that do not fit development objectives or development ignoring possibilities set by research output. The disintegration may also imply friction, mistrust, waste of resources, and loss of opportunities for new businesses and products or not adapting to market changes. In this sense, the integration between $R$ and D can be seen as a dynamic capability (DC).

Some studies have characterized and differentiated R from $D$, including identifying more sub-divisions, for example, the Frascati Manual $(O E C D, 2015)$ and the classification made by the U.S. Department of Defense (Amsden \& Tschang, 2003). This study adopts a simpler division: "R" for "Research" responsible for the development of new technologies, and "D" for "Development" responsible for materializing this technology in the form of new products (Boutellier, Gassmann, \& Von Zedtwitz, 2000).

One researcher who studied the integration between $R$ and $D$ in depth was Marco lansiti in the 1980 s and in the onset of the 1990s. He, in partnership with Kim Clark, wrote in 1994, a paper evaluating the problem of integration between $R$ and $D$ from the perspective of DCs, an approach still in formation (Iansiti \& Clark, 1994). At that time, the most relevant work available was a working paper-the study of 1992 by Teece, Pisano, and Shuenwhich evolved into the seminal paper written by these authors in 1997 (Teece, Pisano, \& Shuen, 1997).

The DC approach is not a fully unified theory given the number of definitions that have been proposed over the past 25 years. Some authors have sought to elucidate the reasons for the non-consolidation of the concept. Specifically, we believe that
Di Stefano, Peteraf, and Verona (2014) were able to combine the distinctions into one model, which we explore later in this paper.

One area where there is consensus is that departmental (organizational function) integration is one of the basic mechanisms for the formation, maintenance, and deployment of a given $D C$ in an organization. This mechanism will be explored in the case of the technological integration between $R$ and $D$.

Therefore, our research question is: how can the $D C$ approach be used to analyze the integration between $R$ and $D$ when they are separated departments? To find the answer, we conducted a systematic literature review in order to organize the field and identify gaps, culminating with the proposition of a research agenda which is presented in the following sections of this paper.

\section{METHODOLOGY}

The literature review was divided into three groups: the first relates to the understanding of the relationship between $\mathrm{R}$ and $\mathrm{D}$, the second relates to the evolution of the DC field, and the third is the intersection of the first two.

For the first group, we followed three techniques suggested by Levy and Ellis (2006): keyword searching, backward searching, and forward searching. For other authors, for example, Ridley (2012), the backward and forward searching is known as the "snowball" technique. Using two main available databases, Web of Science ${ }^{\circledR}$ and Scopus ${ }^{\circledR}$, we did keyword searching in February of 2018 and chose Scopus ${ }^{\circledR}$ to continue the literature review process as subject area was broader than in the Web of Science ${ }^{\circledR}$. The initial search used "research", "development" and "integration" as strings in articles titles, abstracts, and keywords. The vast majority of articles considered $R$ and $D$ as a single department and the problem of integration related to departments such as marketing. i.e., this search did not fit with our main characteristic, which considered $R$ and $D$ as different departments.

Therefore, we eliminated "integration" from the search field and added "split or separation" as a new string. The database returned more than 12,800 documents so we restricted the subject area to "business, management and accounting" in the available subject list. This new cycle brought 392 documents, which were classified by citation order. By reading the titles and abstracts, and the full article to see whether it fit our interest, we found the article by Chiesa (1996), which we believed was the one that best fit our research.

We conducted another search round with "research", "development" and "technology integration" in the business 
subject. This resulted in 1133 documents; we added a new string "product" to reduce this number to 379 documents. Using the same steps of the previous search, we selected the article of lansiti (1995a).

Assuming that the keywords for our study are widely used in different fields of science, using two articles that closely fit our research aim, we began the "snowball" technique through the references cited by Chiesa (1996) and/or lansiti (1995a) backward searching, and in publications that referenced at least one of these articles - forward searching.

Starting from the research question, we looked for theoretical approaches we could use to study it. We chose the DC concept owing to its relationship with the field of strategy and also due to the possibility of evaluating the problem of integration in the face of the evolution that this approach has seen in the last 25 years. This led us to the second grouping in our literature review.

In this field of DCs, the studies of Teece et al. (1997) and Eisenhardt and Martin (2000) are the two most cited studies but present divergent ideas, which we explore later in this paper. By searching the database with the aim of understanding other references that could better explain the differences between these studies in more depth, and ordering the number of citations, we identified studies by Wang and Ahmed (2007) and the set of papers by Peteraf, Verona, and Di Stefano (2013) and Di
Stefano, Peteraf, and Verona (2010; 2014). Using the "snowball” technique, we also found a book edited by Helftat in 2007 and other conceptual studies in other fields related to DCs. Special issues from the California Management Review in 2016 and RAERevista de Administração de Empresas in 2017 were also included in this literature review, which, based on their recent publication dates, did not appear among the most cited, adding relevant references based on their contribution to our subject.

For the third grouping of our literature review, we looked for references that integrated the first and second groups. The most relevant study was from lansiti and Clark (1994), which had "integration" and "dynamic capability" in its title. From this key paper, we did a forward search to find other references, which we discuss later such as Woiceshyn and Daellenbach (2005) and Helfat and Campo-Rembado (2016).

\section{INTEGRATION BETWEEN RESEARCH AND DEVELOPMENT}

The result of the first group of the literature review is an understanding of the relationship between Research and Development as synthesized in Exhibit 1.

\section{Exhibit 1. References in the interface between research and development/integration of new technologies and product development/internal technology transfer}

\begin{tabular}{|c|c|c|c|c|}
\hline Author(s) & Overview & $\begin{array}{l}\text { Departmental } \\
\text { separation }\end{array}$ & $\begin{array}{l}\text { Examples of } \\
\text { integration } \\
\text { mechanisms }\end{array}$ & Context \\
\hline $\begin{array}{l}\text { Cohen, Keller, } \\
\text { \& Streeter } \\
\text { (1979) }\end{array}$ & $\begin{array}{l}\text { Existence of primary factors (e.g., } \\
\text { complete technical knowledge, } \\
\text { comprehension of the potential of growth } \\
\text { of technology), and secondary elements } \\
\text { (e.g., timeliness/ opportunity, senior } \\
\text { leadership involved), which affect the } \\
\text { technology transfer. }\end{array}$ & $\begin{array}{l}\text { Explicit: “transfer } \\
\text { of technology } \\
\text { from research to } \\
\text { development” (p. 11). }\end{array}$ & $\begin{array}{l}\text { Joint programs } \\
\text { (e.g., development } \\
\text { people in research } \\
\text { laboratories and } \\
\text { research activities } \\
\text { in development } \\
\text { laboratories) are two } \\
\text { of primary factors }\end{array}$ & $\begin{array}{l}\text { Study based on } 18 \\
\text { projects in IBM published } \\
\text { by three of its executives. }\end{array}$ \\
\hline
\end{tabular}




\section{Exhibit 1. References in the interface between research and development/integration of new technologies and product development/internal technology transfer}

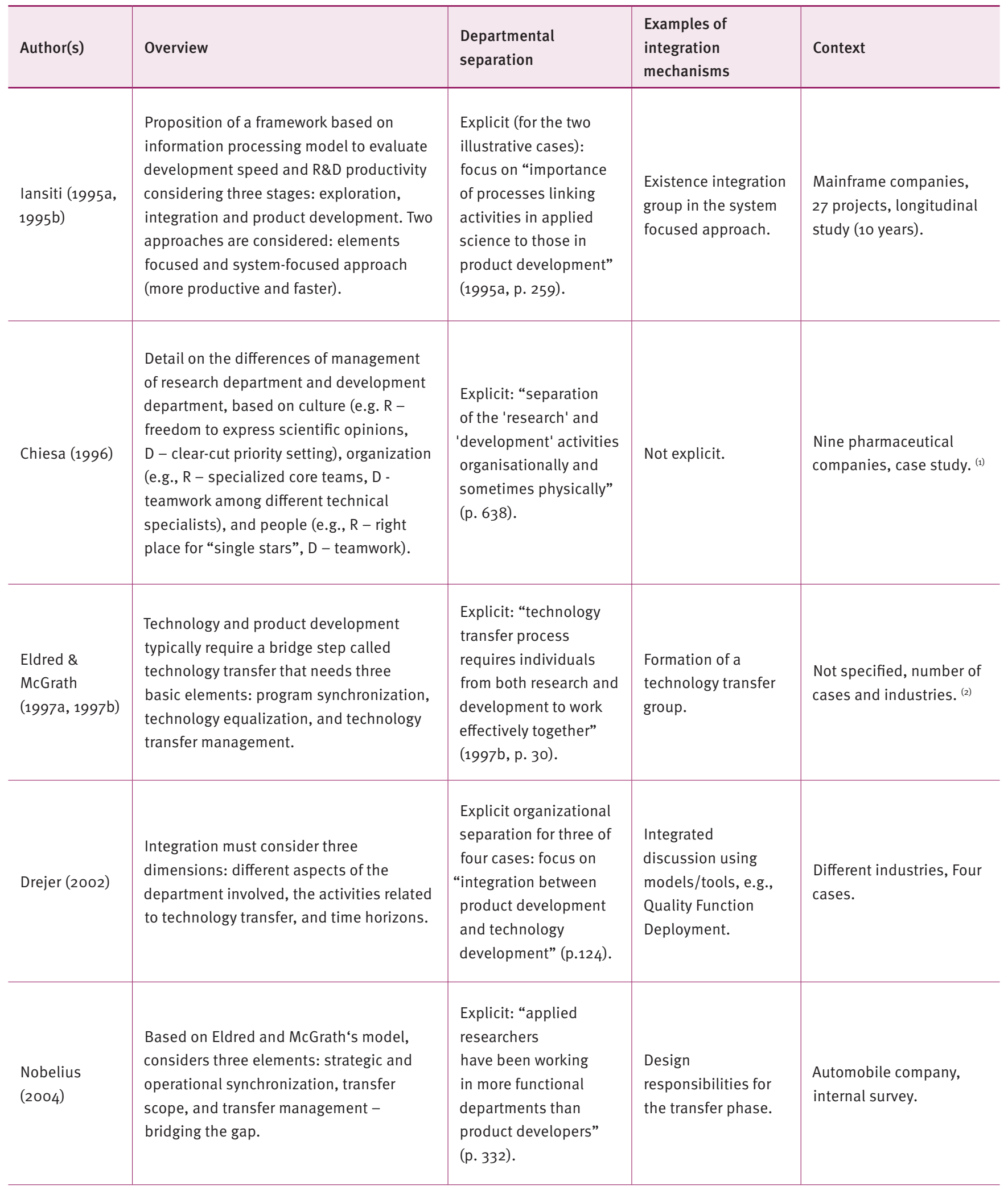




\section{Exhibit 1. References in the interface between research and development/integration of new technologies and product development/internal technology transfer}

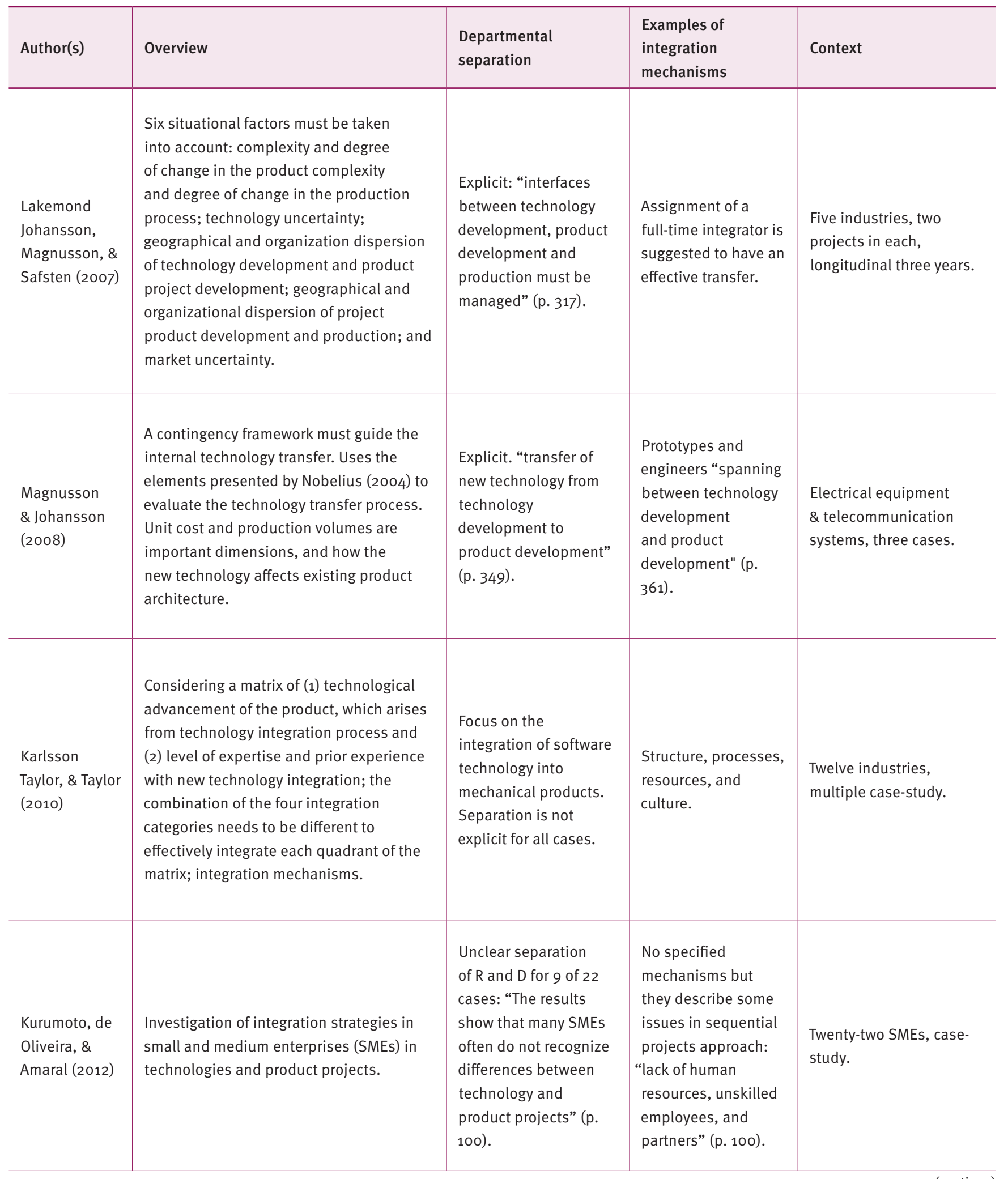




\section{Exhibit 1. References in the interface between research and development/integration of new technologies} and product development/internal technology transfer

\begin{tabular}{l|l|l|l|l}
\hline Author(s) & Overview & $\begin{array}{l}\text { Departmental } \\
\text { separation }\end{array}$ & $\begin{array}{l}\text { Examples of } \\
\text { integration } \\
\text { mechanisms }\end{array}$ & Context \\
\hline $\begin{array}{l}\text { Schuh \& Apfel } \\
(2014)\end{array}$ & $\begin{array}{l}\text { Reference exhibit where each project can } \\
\text { plan its transfer project, considering: } \\
\text { transfer process, transfer object, } \\
\text { situational context, requirements, transfer } \\
\text { elements, and type-based configuration. }\end{array}$ & $\begin{array}{l}\text { Explicit: "transfer } \\
\text { processes between } \\
\text { technology development } \\
\text { and product } \\
\text { development" (p. 357). }\end{array}$ & Not explicit. & $\begin{array}{l}\text { Experience from } \\
\text { consultancy projects. }\end{array}$ \\
\hline
\end{tabular}

(1) In the article, Chiesa refers to a survey based on a literature analysis and interviews. We consider this a case study.

(2) The authors were directors of a management consulting firm for technology-based companies. We assume that the model proposed was based on this experience.

We analyzed two factors looking for similarities: organizational separation and examples of integration mechanisms described in the studies. Even when not naming $R$ and $D$ as separated functions, the majority of the models indicate that technology is developed by one organizational unit and product development is conducted by another. As examples of integration mechanisms, we highlight the importance of integration/technology transfer groups as a mechanism that facilitates the application of new technologies into products.

The literature shows some diverse studies concerning the models for integration between $R$ and $D$, ranging from abstract models to pragmatic ones, from in-depth case studies to surveys, varying industries, and author backgrounds (executives, consultants, academics). There is no consensus on the theoretical basis that should be utilized to discuss how new technologies could be better integrated into new product development; the two oldest studies do not even present any theoretical foundation.

To address this, we anchor our study in a broad theoretical approach to allow for a high degree of generalization, considering the contingency factors that must be considered when applying this approach to a company's reality. Our theoretical basis is the DC concept, which we detail in the next section.

\section{DYNAMIC CAPABILITIES}

\section{Definitions}

The concept of the DC achieved relevance in the 1990s as an extension of the resource-based view (RBV) since this theory has static elements (Eisenhardt \& Martin, 2000). In addition, the RBV does not explain how resources can be recreated or reconfigured (Ambrosini \& Bowman, 2009) or the reasons why some firms have a competitive advantage in situations of rapid change (Teece et al., 1997). The DC concept enhances the RBV because it shows the evolution of organizational resources and capabilities in the face of changes in the environment and also allows for the identification of specific processes in these organizations that evolve (Wang \& Ahmed, 2007).

DCs are especially relevant for companies in competitive environments with certain characteristics. Specifically, where technological changes are systematic and where various inventions need to be combined to create products and/or services that meet consumers' needs (Teece, 2007), preventing organizations from creating internal rigidities and from hindering the development of innovation (Leonard-Barton, 1992).

Despite a considerable amount of publications on DCs, the discussions have not always been unified (Teece, 2014). The development of the theory, dissociated from empirical research, has focused on individual cases without searching on common aspects, contributing to the lack of consensus (Wang \& Ahmed, 2007), similar to other theoretical approaches in the field of strategy that were developed in a fragmented way (Takahashi, Bulgacov, Bitencourt, \& Kaynak, 2017).

The seminal works in this field are those of Teece, Pisano, and Shuen, in 1997 and of Eisenhardt and Martin in 2000 (Peteraf et al., 2013). Their definitions of DCs are as follows:

We define dynamic capabilities as the firm's ability to integrate, build, and reconfigure internal and external competencies to address rapidly changing environments (Teece et al., 1997, p. 516).

The firm's processes that use resources - specifically the processes to integrate, reconfigure, gain and release resources - to match and even create market change. Dynamic capabilities thus are the organizational and strategic routines by which firms achieve new resource configurations as the markets emerge, collide, split, evolve, and die. (Eisenhardt \& Martin, 2000, p. 1107) 
In an attempt to unify this concept, Helfat (2007) defined DC as follows: "A dynamic capability is the capacity of an organization to purposefully create, extend, or modify its resource base" ( $p$. 1). Thus, this means that DCs consist of practical and in a certain degree of standardized sets of intentional activities rather than sources of chance or luck (Helfat, 2007).

Another definition that seeks the unification of concepts but is based on the literature review is that of Wang and Ahmed (2007):

We define dynamic capabilities as a firm's behavioral orientation to constantly integrate, reconfigure, renew and recreate its resources and capabilities, and most importantly, upgrade and reconstruct its core capabilities in response to the changing environment to attain and sustain competitive advantage. (p. 35)

\section{Dynamic capabilities foundations and organizational processes}

DCs are directly related to intentional changes and the processes used are associated with searching, decision-making, and management of these changes (Maritan \& Peteraf, 2007). These processes connect action and evolution using the knowledge acquired through the effective execution of the problem-solving process (lansiti \& Clark, 1994). Teece et al. (1997) argue that competitive advantage relates to the market position of each firm's organizational and its managerial processes, considering its "positions" (specific intellectual assets) and paths (strategic choices) by which these can be developed, including path dependence.

DCs are not resources but processes that act on resources, building the future basis of these resources and renewing or adapting existing resources to the changes that the environment demands (Ambrosini \& Bowman, 2009). These processes are in a certain extent process embedded in the "traditional" processes of the organization and require more than a process design; rather, they require a high involvement of leadership and tacit knowledge of the organization (Wang \& Ahmed, 2007).

Maritan and Peteraf (2007) argue that processes are mechanisms by which DCs are put into practice and mechanisms by which dynamic capacities are developed. Consequently, processes play the role of development and deployment for DCs.

Organizational and managerial processes have three main functions: coordination/integration of activities for the correct delivery of products and services; acquisition of knowledge from these activities so they can be carried out more efficiently; and reconfiguration of resources needed to respond to changes in the environment (Teece et al., 1997). Together, they can be thought of as "asset orchestration processes" and, as far as the most valuable assets are concerned, which are knowledge-related, they cannot be easily transferred to another organization. The coordination and integration of these assets create value that cannot be replicated in the market (Teece, 2007).

Teece (2007) explores the concept of micro-foundations of dynamic capacities to differentiate the elements that support the capabilities of the dynamic capability itself. The micro-foundations are the "distinct skills, processes, procedures, organizational structures, decision rules, and disciplines - which undergird enterprise-level sensing, seizing, and reconfiguring capacities are difficult to develop and deploy" (p. 1319). These micro-foundations can be grouped into three categories: (1) sensing, (2) seizing, and (3) managing/transformation of opportunities and threats. Sensing, which also considers the formatting of opportunities and threats, encompasses activities related to searching, creating, learning, and interpretation. Seizing involves activities related to the selection of the opportunities and threats identified in the sensing stage and this includes decision-making activities and the subsequent execution of marketing or technological opportunities (or threat mitigating actions) made tangible in products and services for consumers and receiving high investment by the organization. Finally, in managing/transformation, the activities are related to the combination, reorganization, and protection of existing assets in the company (Teece, 2007).

In accordance with Teece et al. (1997), Bowman and Ambrosini (2003) emphasize that dynamic capabilities are built/developed and cannot be purchased. These authors propose four types of processes for creating new resources and assets: reconfiguration, leverage, learning, and integration. Reconfiguration refers to the transformation and recombination of assets and resources whether they are from supporting activities or core processes; leverage refers to the process replication or extension of existing resources in new domains or units; learning refers to the most efficient and most effective performance of the activities obtained by repetition and experimentation through a culture that supports such learning or through rigid controls over activities; and integration refers to the ability to coordinate and integrate resources and assets from different sources in a coherent way.

Wang and Ahmed (2007) also present the concept of aggregation. As stated by these authors, DCs are supported by three types of common factors: adaptive capability, absorptive capability, and innovative capability along with the underlying processes of integration/adaptation, reconfiguration, renewal, 
and recreating of resources. Adaptive capability refers to the identification of and capitalization on emerging market opportunities and knowing how to balance exploration and exploitation strategies; absorptive capability refers to the company's ability to recognize the opportunity derived from external knowledge and to apply it for commercial purposes; and innovative capability refers to the organization's ability to develop products and markets through strategic alignment with innovative processes and behaviors. These three types of capabilities are correlated but conceptually distinct: the adaptive focus is on internal flexibility; the absorption focus is on internalization of external knowledge; and the innovation focus is on the link between the use of resources in products/services generated by the organization (Wang \& Ahmed, 2007).

Figure 1. Equivalence of DC concepts among authors

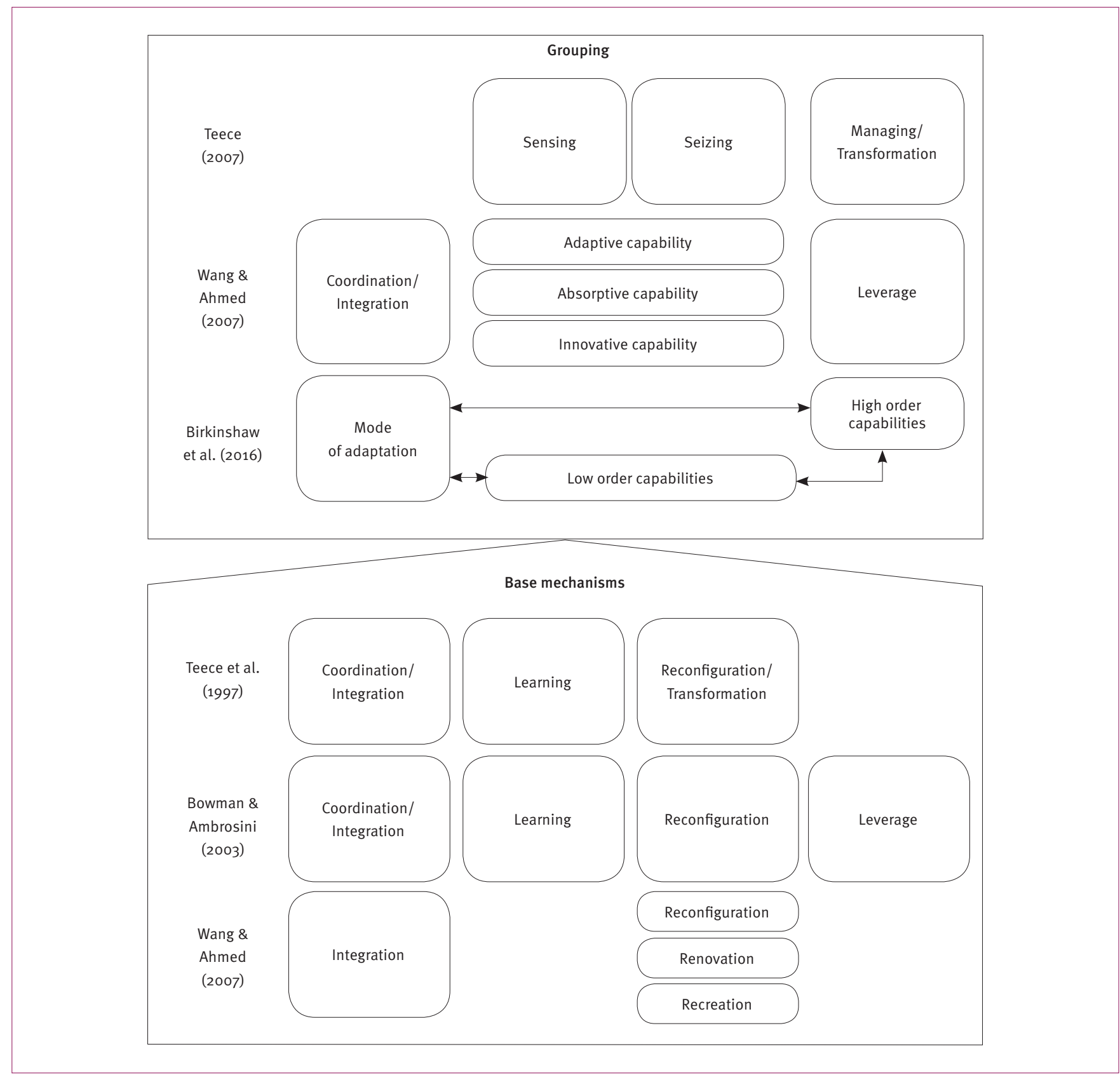


Birkinshaw, Zimmermann, and Raisch (2016), studying organizational ambidexterity, specifically three forms of a firm's modes of adaptation (structural separation, behavioral integration, and sequential alternation), proposed a modification to Teece's (2007) linear view of sensing, seizing, and managing/transformation. Sensing relates to the exploration and seizing relates to the exploitation of opportunities and are viewed as low-order capabilities typically involving frontline managers. Managing/transforming refers to a high-order capability developed and implemented by top executives and involving choosing a mode of adaptation, allowing exploration and exploitation to occur, and managing/transforming are complementary assets needed for the (ambidexterity) mode of adaptation chosen.

Figure 1 visually presents the alignment among these concepts.

\section{Different views on the DCs approach}

There is no general consensus around the DCs concept in the academic community, as confirmed in our review presented in the "Definitions" section above They are seen as a source of competitive advantage for organizations by some authors but others do not even acknowledge their existence (Winter, 2003).

Collis (1994) uses the concept of organizational capabilities and argues that the competitive advantages based on such capabilities are vulnerable to the actions of competitors with a higher order capability. According to this author, the first capability (static) is related to the basic activities of the organization; the second capability (dynamic) is related to the improvements in these activities; and the third (creative) is related to the strategic insights that allow the firms to recognize the value of their resources or develop new strategies ahead of the competition. A more valuable qualification is the "ability to innovate the structures that innovate the structures that produce better product innovation" (Collis, 1994, p. 144).

Exemplifying this classification, Alves, Barbieux, Reichert, Tello-Gamarra, and Zawislak (2017) propose an assessment model of innovation. They conclude that operational capabilities are ordinary because they have little influence on innovation performance, management, and development. Whereas, transactional capabilities are in fact DCs that can explain better the firm's innovative performance.

As stated by other scholars, the real influential factors on DCs are different: Teece et al. (1997) stated that DCs represent the skills to achieve a new form of competitive advantage, whereas according to Eisenhardt and Martin (2000), DCs are necessary conditions but not sufficient for competitive advantage; therefore, they are not the only source of this advantage because, in the long term, competitors tend to arrive, even if by different paths, to the same level of capabilities. Moreover, the two seminal studies differ profoundly in terms of their conceptual basis, boundary conditions, and applicability in rapidly changing markets (Peteraf et al., 2013).

In a set of three papers published in 2010, 2013, and 2014, researchers Di Stefano, Peteraf, and Verona conducted a bibliometric evaluation of DCs to understand the divergence in this field of study. Seeking a solution to the existing theoretical conflicts, they proposed a form of unification (Di Stefano et al., 2010). They concluded that researchers in the field of technology and organizational performance and strategy used the study of Teece et al. (1997) as a main reference, while researchers in organizational processes and information systems used the study of Eisenhardt and Martin (2000) as a theoretical basis (Peteraf et al., 2013).

According to Teece (2014), the reason for this divergence lies in the capability class that each study used as a reference: whether the capabilities are ordinary capability or whether they are dynamic. Ordinary capabilities are those related to the current performance of organizations and DCs are those directing ordinary activities towards high-return challenges. This aligns with the concept of Collis (1994), however, considers any superior order of capability as dynamic.

Continuing this discussion, Teece, Peteraf, and Leih (2016) affirm that ordinary capabilities cannot help an organization create volatility and/or surprise, positive or negative, while DCs give an organization agility. In this context, management must equilibrate agility and efficiency (minimizing operational cost to a particular agility level) requiring long-term commitment and avoid short-term cost cutting, for example, to support innovation strategy.

According to Teece (2014), there has been a misinterpretation/reformulation of Eisenhardt and Martin's study (2000) on the DC framework, claiming that all types of capabilities can become best practices.

As a point of conciliation between these views, Peteraf et al. (2013) argue that under certain contingencies it is possible that DCs are sources of sustainable competitive advantage in cases of rapidly changing technological environments. These authors propose the conciliation based on: (1) the ability of organizations to continuously create and deploy rules and simple routines from more complex capabilities; (2) the broad applicability of these rules and simple routines; and (3) the consideration that simple 
rules and routines are a bundle of resources and capabilities of the organization, although not the whole portfolio of capabilities. Consistent with Peteraf et al. (2013), Wang and Ahmed (2007) argue that the heart of the DC is the ability to apply resources and capabilities quickly and astutely and fortuitously, changing these into products and services that deliver more value to customers.

Di Stefano et al. (2014) argue that the main reason for these differences in the various definitions of DCs is due to the theoretical bases used: the most relevant is the RBV but other theories have also influenced this field such as the knowledge-

\section{Exhibit 2. Differences between DC definitions}

based view, behavioral theory, evolutionary economics, network theory, transaction cost economics and, finally, the positioning view. In considering the seminal studies, Eisenhardt and Martin's (2000) is closer to behavioral and organizational theory than that of Teece et al. (1997), which is based on the RBV but also uses economic logic (Di Stefano et al., 2014). This study of 2014 also extends bibliometric analysis through a content analysis of the existing definitions of DC made by several researchers. Five domains are listed where different approaches are used to define this concept. Exhibit 2 lists these differences.

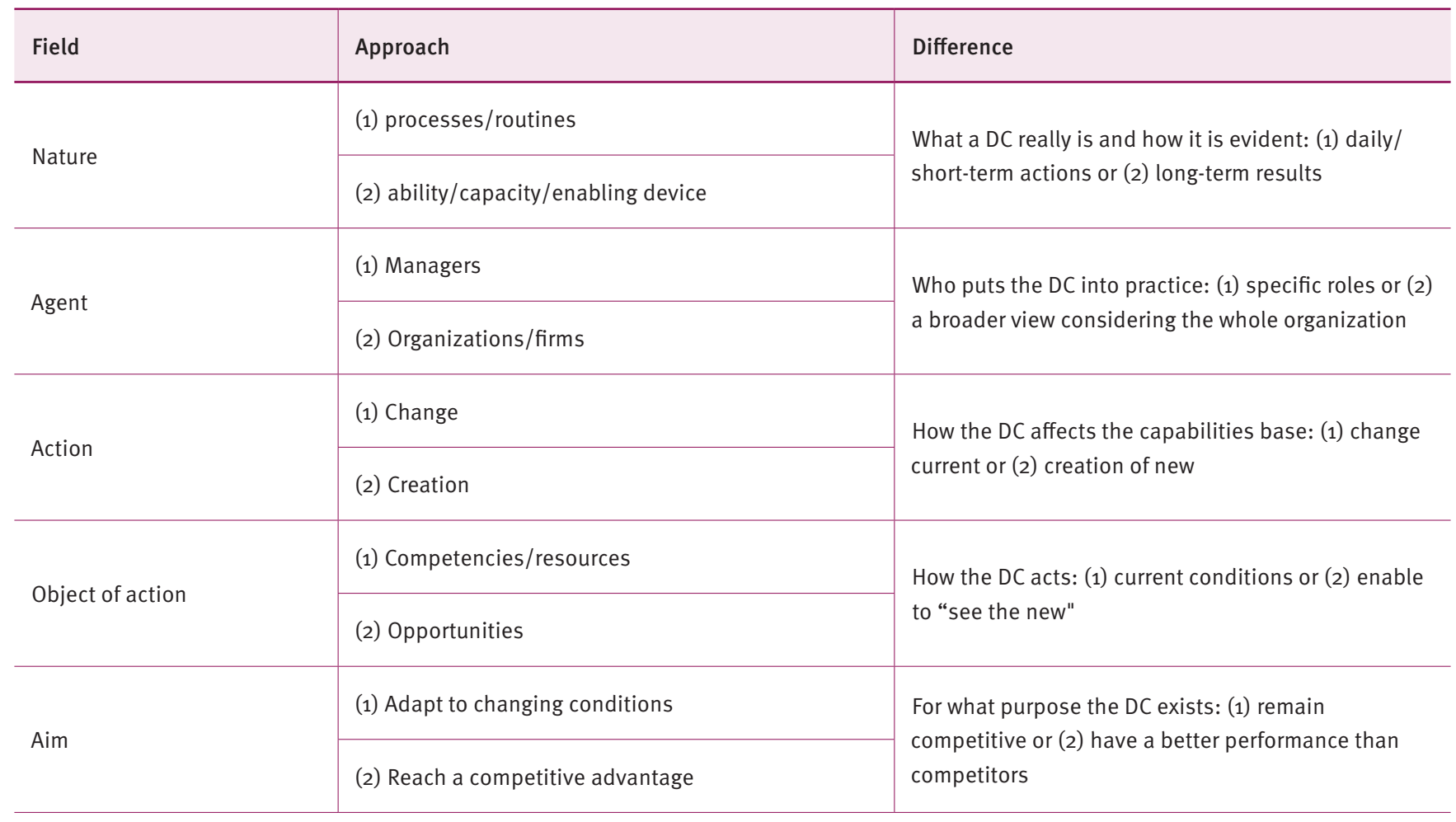

Source: Adapted from Di Stefano et al. (2014)

\section{A conciliatory model}

The discussion of DCs will eventually evolve as the different approaches in this field are combined (Takahashi et al., 2017). One proposal is the model of Di Stefano et al. (2014) that considers the two seminal conceptual bases as parts of a larger interconnected system, using a metaphorical analogy of a bicycle's drivetrain. Figure 2 in the next section presents this analogy with modifications proposed for the study of the integration between research and development.

According to these authors, simple rules and complex routines co-exist within organizations. The crankset represents the simplest rules, where top managers select and control them (in the bicycle metaphor is the rider that moves the pedals on the crankset). Complex routines, represented by the freewheel, are the mechanisms by which organizations use to deploy and manage changes. The chain connects these two types of actions, coordinating the dynamic movement between them and the derailleur represents the coupling and decoupling mechanisms of these devices, which allows flexible adjustments for environmental changes (Di Stefano et al., 2014).

Therefore, as stated by Di Stefano et al. (2014), regarding the point of views of Teece et al. (1997) and Eisenhardt and Martin (2000), if the DCs are complex routines or, if they are simple rules, these are not opposing or contradictory visions but 
rather complementary visions. The achievement of competitive advantage is not explained by a single factor but by a series of interconnected components.

\section{INTEGRATION BETWEEN RESEARCH AND DEVELOPMENT THROUGH THE LENS OF DYNAMIC CAPABILITIES: A NEW APPROACH}

Felin and Powell (2016) affirm that companies that differentiate (in terms of organizational structure) and do not integrate may create organizational chaos with a lot of ideas but a lack of implementation. The combination of highly differentiated and highly integrated mechanisms allows the optimal design for DCs.

As pointed out in the Methodology section, a key study that addresses the intersection of DCs and integration is that of lansiti and Clark (1994). They use longitudinal research to study the product development process at two companies, one in the computer industry and the other in the automobile industry, between 1980 and 1990.

These authors indicate that integration with consumers and technological integration are more related to the development of concepts that respond to new external contingencies. Whereas, the capability for implementation is essentially an internal integration of the organization involving specific skills, knowledge bases, and technical and managerial systems, which directly relate to the performance of the company. They define internal integration as "the capacity for extensive coordination between different specialized subunits within an organization, and explicitly targets the implementation of a given project concept" (lansiti \& Clark, 1994, p. 568). Technological integration is defined as "the capacity to link the evolving basis of technical knowledge (both inside and outside the firm) to the existing basis of capability within the organization" (lansiti \& Clark, 1994, p. 570).

A key role in this process is performed by the "integrators." For the computer company, this role was performed by engineers who, based on their experience (manufacturing environment, and system architecture) and understanding of the possibilities of the new technologies, proposed superior products and implemented them in a very efficient way. At the automobile company, the product managers were the integrators, combining their knowledge of the customer environment and aspects of the development process and were empowered to conceptualize future products and implement them. The integrators merged the existing environment with the new possibilities that the new technologies offered and they shaped the organization with new competencies, evolving the capability base.

The authors also argue that the ability to integrate different knowledge by solving problems in response to several contingencies is the basic foundation for knowledge creation, which then leads to the generation of new capabilities in the organization. The results of the longitudinal research show that the performance of organizations, according to the perspectives of product quality, productivity, and lead times, is directly associated with their capacity for technological integration. The study also shows that knowledge generation, fusion, and accumulation are the essence of integration, uniting knowledge of new technology with the existing capability base in the organization, similar to what Kogut and Zander (1992, p. 392) called “combinational capacities:" "the interest of the capability of the firm to exploit its knowledge and the unexplored potential of the technology". Even being limited to product development, lansiti and Clark (1994) suggest that "our conceptual message has general application in capability building process (p. 602)."

According to Helfat and Campo-Rembado (2016), the integration capability, and its maintenance over time, is an enabler that allows companies that remain vertically integrated to innovate systematically and avoid accruing sunk costs for reintegration when needing to reconfigure linkages between departments/areas of the organization. This constant integration allows knowledge and skills developed in past projects to be exploited in new projects (Marsh \& Stock, 2006).

This knowledge-based integration, which reduces uncertainties related to the transformation of technical knowledge into market products, such as the availability of complementary technologies, among other uncertainties, is a dynamic capability that organizations develop. It is also a source of competitive advantage, leveraging existing capabilities and creating, at the same time, new capabilities in order to build a platform for future product development (Marsh \& Stock, 2006). These capabilities are complex and time-consuming to develop and are the result of an accumulation of many small actions and decisions over the years (Henderson, 1994).

Some activities, such as audits and dissemination of this knowledge through memos and presentations, contribute to the withholding and dissemination of this knowledge, thus contributing to the development and maintenance of integration (Marsh \& Stock, 2006). Iansiti (1995b) emphasizes the importance of specific groups in the integration involved in the routine of the project who may not have the knowledge to perform all project tasks but have a view of the relationship between existing and new technologies/resources. Such personnel make the 
effort to integrate them along with the presence of "T" shaped professionals: deep knowledge of a specific area but are also capable of understanding the project as a whole. Verona and Ravasi (2003) also emphasize that not only are formal mechanisms fundamental but so are informal mechanisms.

In the context of high uncertainty, this internal capability is especially critical because any competitive advantage is temporary and integration is a key factor for the effective adoption of new technologies quickly, before competitors (Woiceshyn \& Daellenbach, 2005), specially in complex products and systems (Chagas Junior, Leite, \& Jesus 2017). In a study of the oil industry, Woiceshyn and Daellenbach (2005) state that internal integration is a factor that also enables the external integration of the company. Moreover, even companies that are adopters, which have more external knowledge available about a new technology, fail to adopt due to a low capacity of internal integration. They also emphasize that it is essential that the development of technology be done while already considering how this technology will be used. In an Embraer case study, Chagas Junior et al. (2017) affirm that some technologies cannot be outsourced because they are so complex and mastering the whole development (technology and product) reduces the systemic uncertainty.
Alves et al. (2017) consider an organization's ability to design its own products and its ability to adapt technology in use for its own needs as measures in their model that evaluates the innovation capabilities of an organization.

Based on the arguments presented in this section and applying the conciliatory model of DCs by Di Stefano et al. (2014), we propose two refinements to this model. The first relates to the importance of generation, fusion, and accumulation of knowledge; what we call in a broad form "knowledge management".

The second refinement correlates to the key role of integrators as presented by lansiti and Clark (1994). We argue that the derailleur that represents the coupling and decoupling mechanisms in the original model, can be replaced by the role of integrators because this role connects simple and complex rules using the firm's knowledge (the chain in the metaphor) to adapt to environmental changes. In the bicycle's drivetrain, the derailleur makes possible to shift the gears needed for better performance in different types of environments (e.g., in the metaphor, a light gear to reduce the power needed by the rider to climb hills or a heavy gear on the flats to gain speed). Figure 2 presents these refinements.

\section{Figure 2. Analogy of a bicycle's drivetrain for integration between $\mathbf{R}$ and $\mathbf{D}$}

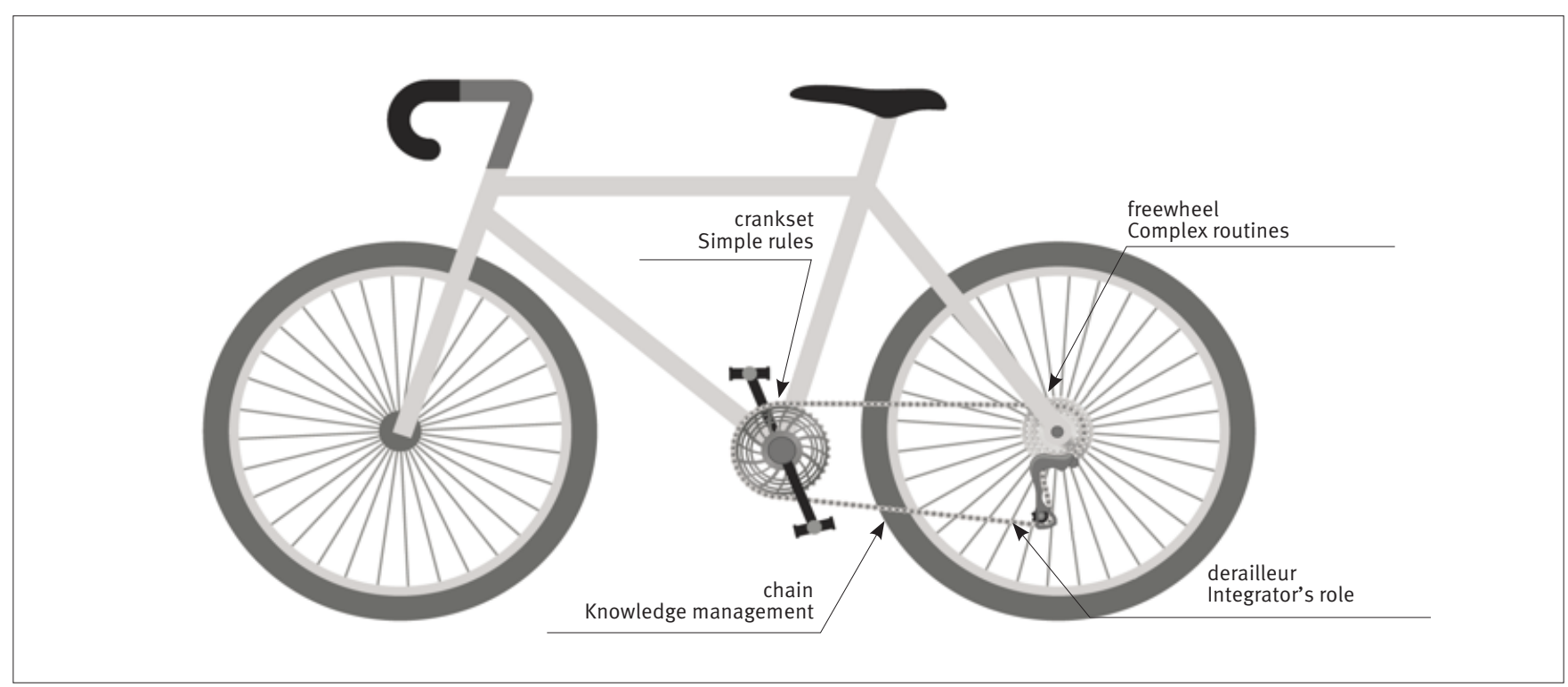

Source: Adapted from Di Stefano et al. (2014)

\section{FINAL REMARKS AND FUTURE RESEARCH}

Our intention in this study was neither to exhaust the discussion on DCs nor solve the problems of the integration between Research and Development. Rather, our aim was to further discuss how this integration problem could be analyzed from the perspective of this still-evolving approach in the field of management. 
We present different models from the literature for the integration between Research and Development. These models have few elements in common and lack robust theoretical support for the most part, which would have helped in generalization.

We demonstrate how the DC approach evolved, from the establishment of the concept in the 1990s, its different definitions, and through the agreement and divergence in this field of study, clarifying the factors behind the divergence as well as the importance of integration that is one of the few elements of consensus in this field. It may be possible that the model presented by Di Stefano et al. (2014) could unite this field of study.

Regarding the integration between $\mathrm{R}$ and $\mathrm{D}$, we propose refinements in the $D C$ conciliatory model, changing "linking mechanisms" to "knowledge management" and "coupling and uncoupling mechanisms" to "integrator's role". These refinements are justified by the nature of this integration, which is based significantly on knowledge, experience, and path dependence. For other kinds of integrations, there could be other refinements.

Future research, especially multiple case studies, may be able to differentiate the simple rules from the complex mechanisms of this interdepartmental interaction, and the role of integrators and knowledge management in this interaction. This, then, may lead to the proposition of new forms of integration and the ways these forms could be better managed, with the ultimate objective is to increase the use of new technologies produced by research in new products generated by development. Our focus here has been on the intra-firm integration of $R$ and $D$, but we suggest that studies could be conducted to apply our proposition to open innovation and networks/ecosystems perspectives. We believe that the integrators' role and knowledge management will be very similar to what we describe in this paper and will involve adapting the simple and complex rules to fit with other kinds of integration.

\section{NOTE}

This article was presented at the 2oth Symposium on Production, Logistics and International Operations Administration (Simpósio de Administração da Produção, Logística e Operações Internacionais [SIMPOI]) in 2017, promoted by the FGV's São Paulo School of Business Administration, Brazil.

\section{REFERENCES}

Alves, A. C., Barbieux, D., Reichert, F., Tello-Gamarra, J., \& Zawislak, P. A. (2017). Innovation and dynamic capabilities of the firm: Defining an assessment model. RAE-Revista de Administração de Empresas, 57(3), 232-244. doi:10.1590/So034-759020170304

Ambrosini, V., \& Bowman, C. (2009). What are dynamic capabilities and are they a useful construct in strategic management? International Journal of Management reviews, 11(1), 29-49. doi:10.1111/j.14682370.2008.00251.x

Amsden, A. H., \& Tschang, F. T. (2003). A new approach to assessing the technological complexity of different categories of R\&D (with examples from Singapore). Research Policy, 32(4), 553-572. doi:10.1016/So048-7333(02)00080-X

Birkinshaw, J., Zimmermann, A., \& Raisch, S. (2016). How do firms adapt to discontinuous change? Bridging the dynamic capabilities and ambidexterity perspectives. California Management Review, 58(4), 36-58. doi:10.1525/cmr.2016.58.4.36

Boutellier, R., Gassmann, O., \& Von Zedtwitz, M. (2000). Managing global innovation: uncovering the secrets of future competitiveness ( 2 a ed.). Berlin, Germany: Springer-Verlag.

Bowman, C., \& Ambrosini, V. (2003). How the resource-based and the dynamic capability views of the firm inform corporate-level strategy. British Journal of Management, 14(4), 289-303. doi:10.1111/j.14678551.2003.00380.x

Chagas Junior, M. de F., Leite, D. E. S., Jesus, G. T. de. (2017). "Coupled processes" as dynamic capabilities in systems integration. RAE Revista de Administração de Empresas, 57(3), 245-257. doi:10.1590/ So034-759020170305

Chiesa, V. (1996). Separating research from development: Evidence from the pharmaceutical industry. European Management Journal, 14(6), 638-647. doi:10.1016/S0263-2373(96)00060-6

Cohen, H., Keller, S., \& Streeter, D. (1979). Transfer of technology from research to development. Research Management, 22(3), 11-17. doi:10 $.1080 / 00345334.1979 .11756535$

Collis, D. J. (1994). Research note: How valuable are organizational capabilities? Strategic Management Journal, 15(S1), 143-152. doi:10.1002/smj.4250150910

Di Stefano, G., Peteraf, M., \& Verona, G. (2010). Dynamic capabilities deconstructed: A bibliographic investigation into the origins, development, and future directions of the research domain. Industrial and Corporate Change, 19(4), 1187-1204. doi:10.1093/icc/dtq027

Di Stefano, G., Peteraf, M., \& Verona, G. (2014). The organizational drivetrain: A road to integration of dynamic capabilities research. The Academy of Management Perspectives, 28(4), 307-327. doi:10.5465/ amp. 2013.0100

Drejer, A. (2002). Integrating product and technology development. International Journal of Technology Management, 24(2-3), 124-142. doi:10.1504/IJTM.2002.003048

Eisenhardt, K. M., \& Martin, J. A. (2000). Dynamic capabilities: What are they? Strategic Management Journal, 21(10-11), 1105 1121.doi:10.1002/1097-0266(200010/11)21:10/11<1105::AID-SMJ133’3.0.CO;2-E 
Eisenhardt, K. M., \& Sull, D. N. (2001). Strategy as simple rules. Harvard Business Review, 79(1), 106-119. Retrieved from https://hbr. org/2001/01/strategy-as-simple-rules

Eldred, E., \& McGrath, M. (1997a). Commercializing new technology - I. Research Technology Management, 40(1), 41-47. doi:10.1080/08956 308.1997.11671102

Eldred, E., \& McGrath, M. (1997b). Commercializing new technology - II. Research Technology Management, 40(2), 29-33. doi:10.1080/0895 6308.1997.11671114

Felin, T., \& Powell, T. C. (2016). Designing organizations for dynamic capabilities. California Management Review, 58(4), 78-96. doi: 10.1525/cmr.2016.58.4.78

Helfat, C. E. (2007). Dynamic capabilities: Foundations. In C. Helfat, S. Finkelstein, W. Mitchell, M. Peteraf, H. Singh, D. Teece, \& S. Winter (Eds.), Dynamic capabilities: Understanding strategic change in organizations (pp. 30-45). Oxford, UK: Blackwell Publishing.

Helfat, C. E., \& Campo-Rembado, M. A. (2016). Integrative capabilities, vertical integration, and innovation over successive technology lifecycles. Organization Science, 27(2), 233-504. doi:10.1287/ orsc. 2015.1045

Henderson, R. (1994). The evolution of integrative capability: Innovation in cardiovascular drug discovery. Industrial and Corporate Change, 3(3), 607-630. doi:10.1093/icc/3.3.607

Iansiti, M. (1995a). Technology development and integration: An empirical study of the interaction between applied science and product development. IEEE Transactions on Engineering Management, 42(3), 259-269. doi:10.1109/17.403744

lansiti, M. (1995b). Technology integration: Managing technological evolution in a complex environment. Research Policy, 24(4), 521-542. doi:10.1016/Soo48-7333(94)00781-0

Iansiti, M., \& Clark, K. B. (1994). Integration and dynamic capability: Evidence from product development in automobiles and mainframe computers. Industrial and Corporate Change, 3(3), 557-605. doi:10.1093/icc/3.3.557

Karlsson, C., Taylor, M., \& Taylor, A. (2010). Integrating new technology in established organizations: A mapping of integration mechanisms. International Journal of Operations \& Production Management, 3o(7), 672-699. doi:10.1108/01443571011057290

Kogut, B., \& Zander, U. (1992). Knowledge of the firm, combinative capabilities, and the replication of technology. Organization Science, 3(3), 383-397. doi:10.1287/orsc.3.3.383

Kurumoto, J. S., de Oliveira, M. G., \& Amaral, D. C. (2012). Technologyproduct integration in SMEs: The unclear separation between the technology and product development. Product: Management \& Development, 10(2), 95-103. doi:10.4322/pmd.2013.003

Lakemond, N., Johansson, G., Magnusson, T., \& Safsten, K. (2007). Interfaces between technology development, product development and production: Critical factors and a conceptual model. International Journal of Technology Intelligence and Planning, 3(4), 317-330. doi:10.1504/IJTIP.2007.016303

LeonardDBarton, D. (1992). Core capabilities and core rigidities: A paradox in managing new product development. Strategic Management Journal, 13(S1), 111-125. doi:10.1002/smj.4250131009
Levy, Y., \& Ellis, T. J. (2006). A systems approach to conduct an effective literature review in support of information systems research. Informing Science, 9, 181-212. doi:10.28945/479

Magnusson, T., \& Johansson, G. (2008). Managing internal technology transfer in complex product development. European Journal of Innovation Management, 11(3), 349-365. doi:10.1108/14601060810889008

Maritan, C. A., \& Peteraf, M. (2007). Dynamic capabilities and organizational processes. In C. E. Helfat, S. Finkelstein, W. Mitchell, M. Peteraf, H. Singh, D. Teece, \& S. Winter, Dynamic Capabilities: Understanding Strategic Change in Organization (pp. 30-45). Oxford, UK: Blackwell Publishing.

Marsh, S. J., \& Stock, G. N. (2006). Creating dynamic capability: The role of intertemporal integration, knowledge retention, and interpretation. Journal of Product Innovation Management, 23(5), 422-436. doi:10.1111/j.1540-5885.2006.00214.x

Nobelius, D. (2004). Linking product development to applied research: Transfer experiences from an automotive company. Technovation, 24(4), 321-334. doi:10.1016/S0166-4972(02)00073-1

OECD (2015). Frascati Manual 2015: Guidelines for collecting and reporting data on research and experimental development. Paris, France: OECD Publishing.

Peteraf, M., Di Stefano, G., \& Verona, G. (2013). The elephant in the room of dynamic capabilities: Bringing two diverging conversations together. Strategic Management Journal, 34(12), 1389-1410. doi:10.1002/smj.2078

Ridley, D. (2012). The literature review: A step-by-step guide for students. London, UK: Sage.

Schuh, G., \& Apfel, K. (2014). Framework to design type-based transfer processes between technology and product development. Management Studies, 2(6), 357-372. doi:10.17265/2328 2185/2014.06.001

Takahashi, A. R. W., Bulgacov, S., Bitencourt, C. C., \& Kaynak, H. (2017) Expanding the dynamic capabilities view: Special contributions. $R A E$ Revista de Administração de Empresas, 57(3), 209-214. doi:10.1590/ So034-759020170302

Teece, D. J. (2007). Explicating dynamic capabilities: The nature and microfoundations of (sustainable) enterprise performance. Strategic Management Journal, 28(13), 1319-1350. doi:10.1002/smj.640

Teece, D. J. (2014). The foundations of enterprise performance: Dynamic and ordinary capabilities in an (economic) theory of firms. The Academy of Management Perspectives, 28(4), 328-352. doi:10.5465/ amp.2013.0116

Teece, D., Peteraf, M., \& Leih, S. (2016). Dynamic capabilities and organizational agility: Risk, uncertainty, and strategy in the innovation economy. California Management Review, 60(4), 13-35. doi:10.1525/cmr.2016.58.4.13

Teece, D. J., Pisano, G., \& Shuen, A. (1997). Dynamic capabilities and strategic management. Strategic Management Journal, 18(7), 509-533. doi:10.1002/(SICl)1097-0266(199708)18:7く509::AIDSMJ882>3.0.CO;2-Z

Verona, G., \& Ravasi, D. (2003). Unbundling dynamic capabilities: An exploratory study of continuous product innovation. Industrial and Corporate Change, 12(3), 577-606. doi:10.1093/icc/12.3.577 
Wang, C. L., \& Ahmed, P. K. (2007). Dynamic capabilities: A review and research agenda. International Journal of Management Reviews, 9(1), 31-51. doi:10.1111/j.1468-2370.2007.00201.x

White, W. (1977). Effective transfer of technology from research to development. Research Management, 20(3), 30-34. doi: 10.1080/00345334.1977.11756416
Winter, S. G. (2003). Understanding dynamic capabilities. Strategic Management Journal, 24(10), 991-995. doi:10.1002/smj.318

Woiceshyn, J., \& Daellenbach, U. (2005). Integrative capability and technology adoption: Evidence from oil firms. Industrial and Corporate Change, 14(2), 307-342. doi:10.1093/icc/dtho53 